〔第50回総会シンポジウム〕

\title{
5. 試料測定領域における貢献と今後の役割
}

荒 井孝

埼玉県立小児医療センター

Key words: Heart disease. Aterial natriuretic peptide, Radio immunoassay, Endothelin, Myosin light chain I.

\section{ROLE OF RADIOIMMUNOASSAY - TODAY AND THE FUTURE-}

\author{
TAKASHI ARAI
}

Department of Radiology Saitama Children's Medical Center

\section{Summary}

For diagnosing heart diseases that use a clinical inspection prior to 1980, a blood biochemical inspection was carried out. However, those evaluations were shown not to be very accurate. After 1980, radioimmunoassay has been used for diagnosing heart diseases. This method has only been developed very recently. It shows the structure and clinical significance regarding endothelin in which the myosin light chain I and arterial natriuretic peptide that are used as the clinical inspection method. This type of diagnosing is expected to have wide applications from now on.

\section{はじめに}

心疾患の診断や経過観察において，核医学試料測定が 従来より果たしてきた役割は大きい。1980年以前は白血 球增加, CRP (C反応性タンパク), CPK(クレアチンキ ナーゼ), GOT(グルタミン酸オキサロ酷酸トランスアミ ナーゼ)，LDH (血清乳酸脱水素酸素) 等の血夜生化学的 検査が行われてきた。しかし，それぞれの評価は必ずし も心疾患の状態を反映するものでなかった，その中で， 心筋梗塞時の代表的マーカーである $\mathrm{CPK}$ および LDH は，細胞質中に存在していることから，虚血により早期 に細胞膜の透過性圥進によって心筋細胞から冕脱してく る。したがって長期にわたる梗塞部位の崩壊と治療経過 に関するマーカーとしては，必ずしも良いものではなか った。

1980年以降には，ミオグロビン，レニン活性，アルド ステロン，心筋ミオシン軽鎖 I，心房性ナトリウム利尿 ホルモン (以下 ANP), エンドセリン等の物質が次々と radioimmunoassay 法により開発され，より心臓の状態 を把握できるようになった。

今回その中で心筋ミオシン軽鎖 I , ANP およびエン
ドセリンの構造および臨床的意義について述べる。

\section{I ，心筋ミオシン軽鎖 I}

心筋ミオシンは心筋細胞内に密に存在し, 筋収縮の中 心的役割を担っている蛋白質で構成されている，構造は 2 本の重鎖と 4 本の軽鎖から成っている，その中で心筋 ミオシン軽鎖 I は，重鎖の頭部に非共有結合で付着して おり，筋原線維の崩壊によりミオシン分子より解離し細 胞外に逸脱して血中に流出してくる（Fig. 1)．血中の心 筋ミオシン軽鎖 I を測定することにより，心筋細胞の障

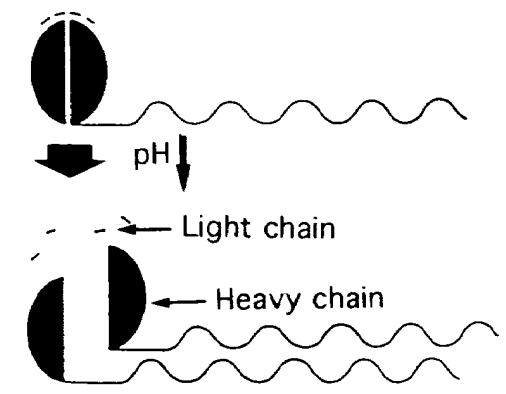

Fig.1 Myosin subunits. 


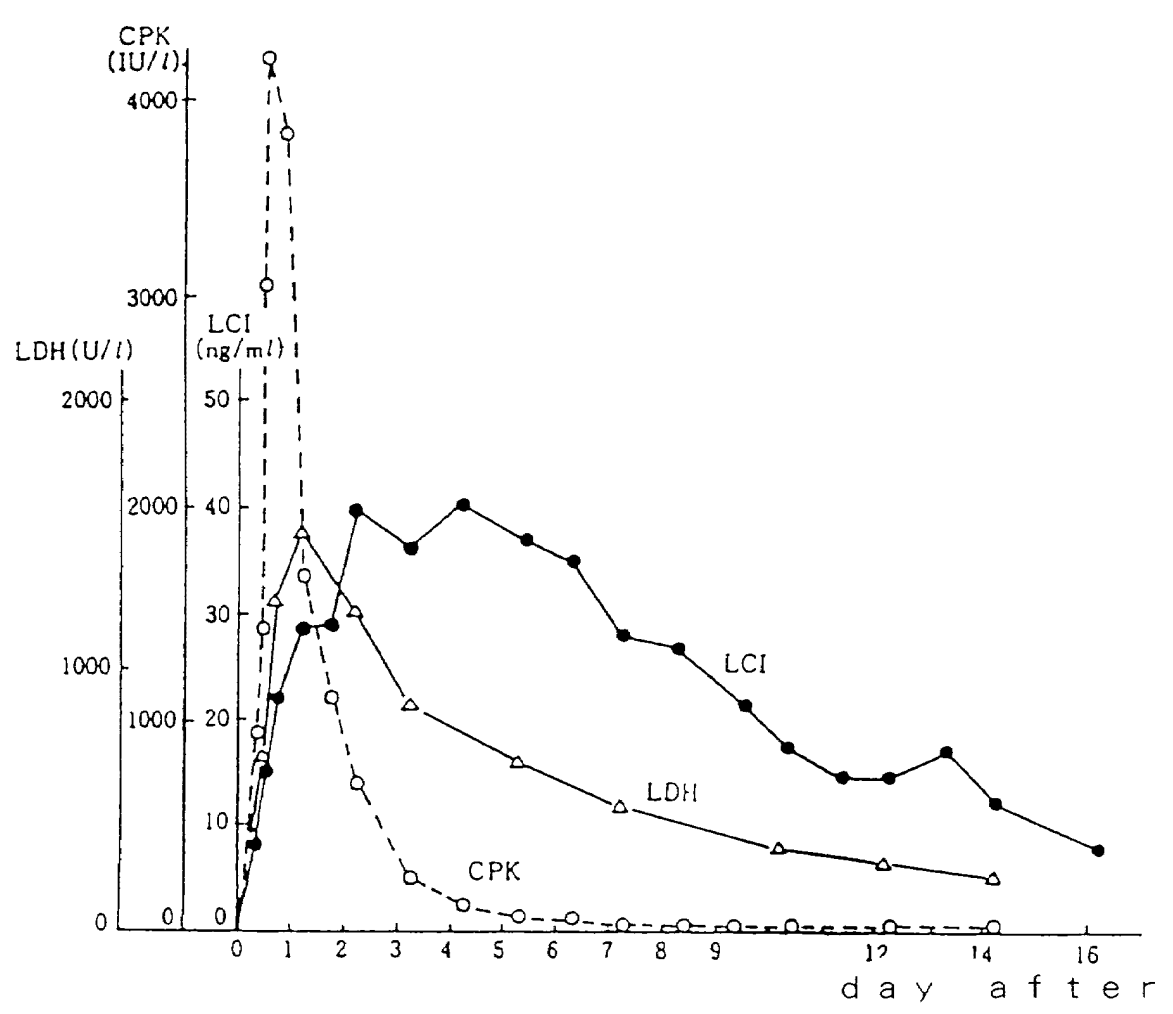

Fig. 2 Results of serial determination of the serum myosin light chain I in a patient with an acute myocardial infarction ${ }^{31}$.

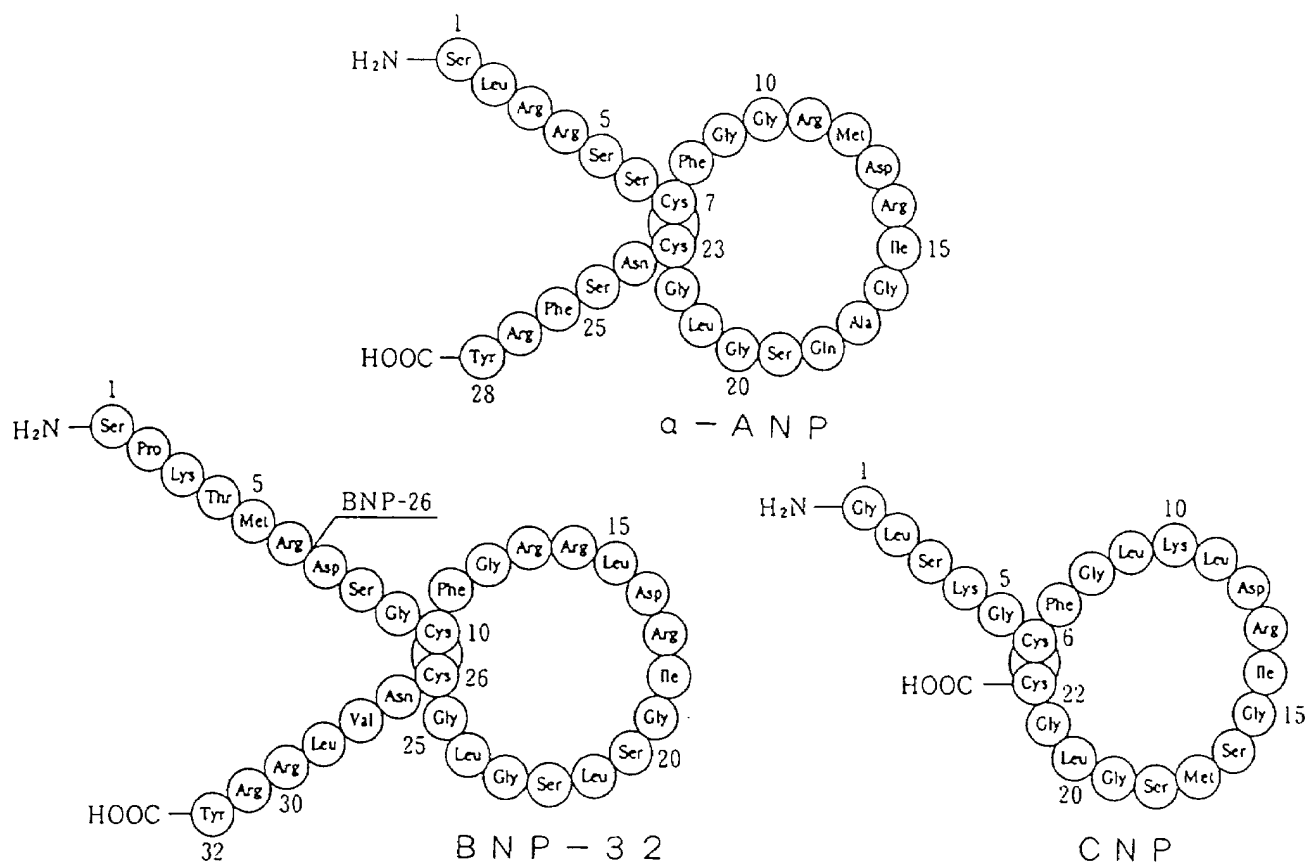

Fig. 3 Natriuretic peptide family.

害の程度を推測することが可能である。また筋原線維の 崩壊とともに放出され，血中クリアランスも早いことか ら, 血中濃度の変動様式により障害心筋の崩壊と治療経 過を知ることができる ${ }^{1,2)}$.

矢崎ら ${ }^{31}$ は, Fig. 2 に示すように心筋梗塞発作時の血
中心筋ミオシン軽鎖 I の経時的変化について検討した。 図に示すように，心筋梗塞発作後 CPK およびLDH は, 細胞質中に存在していることから，虚血により早期に細 胞膜の透過性亢進によって心筋細胞から逸脱してくるた め高値を示す。したがって長期にわたる梗塞部位の崩壊 
と治療経過に関するマーカーとしては問題があった。一 方心筋ミオシン軽鎖 $\mathrm{I}$ は, 心筋梗塞後 6 時間の比較的早 期に上昇し,さらに 1 週間以上の長期にわたって高值を 示す。これは梗塞部心筋の筋原線維の崩壊過程を良く反 映している，さらに血中最高値と梗塞の大きさは，臨床 的に左室駆出率の逆数と相関が認められている. しかし 成田ら"は，左室駆出率は多くの因子に影響され必ずし も心筋梗塞量を反映する指標ではなく，心筋ミオシン軽 鎖 Iのピーク值と ${ }^{99 \mathrm{~m}} \mathrm{~T} \mathrm{C}$-ピロリン酸心筋シンチ断層像 より求めた心筋梗塞量と良好な相関を示すと報告した。

\section{II，心房性ナトリウム利尿ホルモン（ANP）}

1984年に心缄が単に血液のポンプ器官のみならず，ナ トリウム利尿ホルモンを産生し分泌する内分泌器官であ る゙こことが報告された。その後1988年に脳性ナトリウム 利尿ホルモンの(以下 BNP), さらに1990年にはC型ナト リウム利尿ホルモンク（以下 CNP) がそれぞれブタ脳か ら单離された。現在少なくとも 3 種類の ANP ファミリ 一を構成していることが明らかになっている (Fig.3). 心房細胞での ANP の主な分泌刺激は，压・容量負荷に よる心房壁伸展という物理因子である。他にも神経因子, 液性因子（その中には甲状腺ホルモンおよびエンドセり ン等が含まれる)，また頻脈といった刺激も分泌を促進す る. それぞれ刺激が, 核内の遺伝子を発現させ, m-RNA

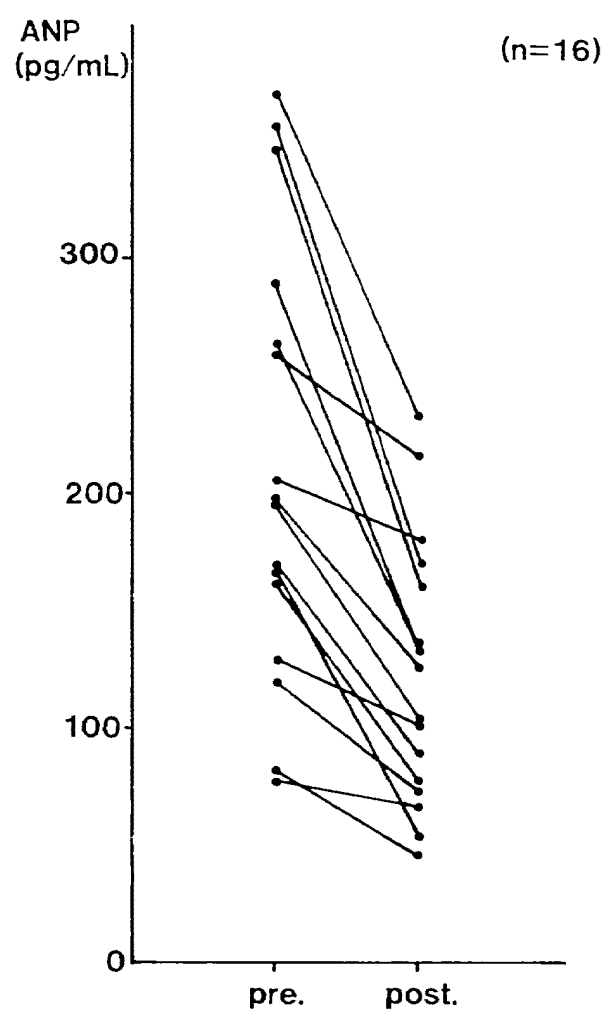

Fig. 4 Results of serial determination of plasma ANP levels in 16 patients with a ventricular septal defect (VSD).
を転写してANPが放出される.また心室細胞では, 心肥 大により ANP が分泌されると考えられている,

小児領域に招ける心室中隔欠損症の治療前後の血獎 ANP 濃度変化について示す (Fig. 4). 16例の患者すべて に, 治療後の病態の改善に伴い血漿 ANP 濃度の低下が 認められた。またファロー四徴症における術前術後の血 獎 ANP 濃度の変化は, 心不全を伴わないため, 術前値は 低值を示すが, 術後に心不全による血奬 ANP 濃度の上 昇が認められる(Fig.5)。さらに蔦本ら ${ }^{10}$ は心不全重症度 の分類と血槳 ANP 濃度の関係について検討した(Fig. 6).

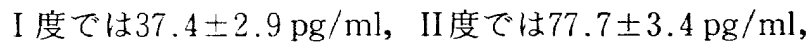

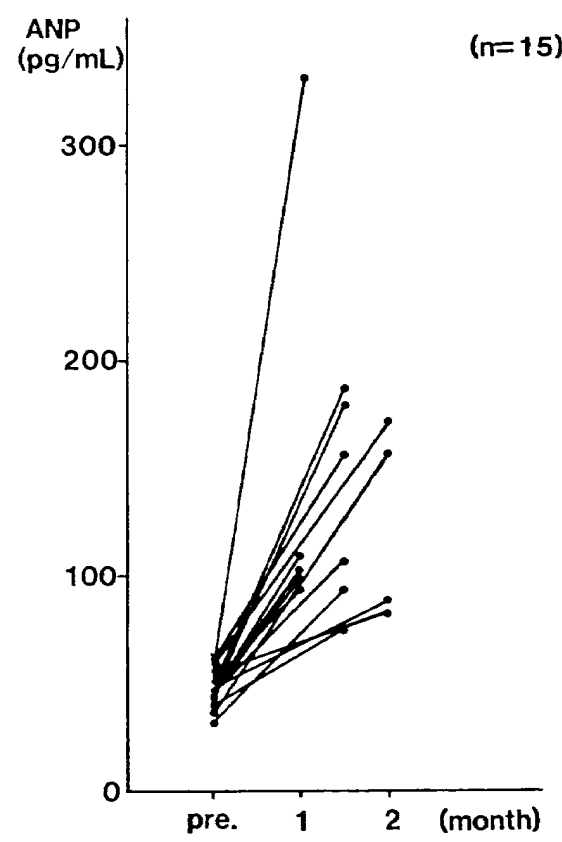

Fig. 5 Results of serial determination of plasma ANP levels in 15 patients with tetralogy of Fallot.

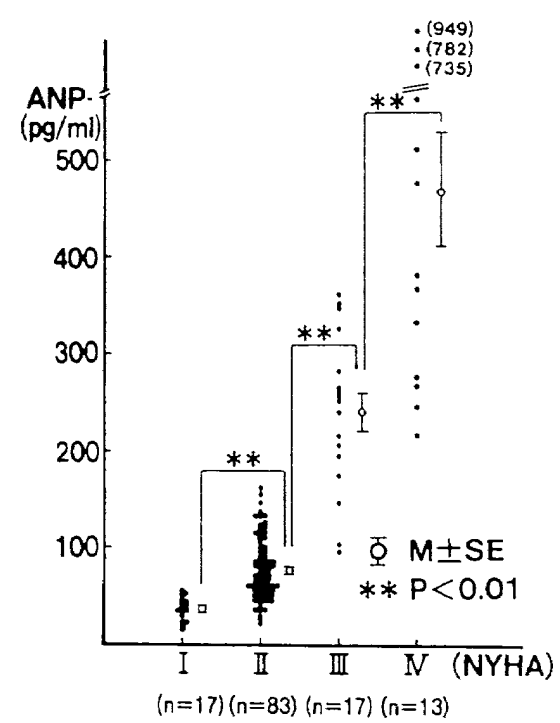

Fig. 6 Assay results of plasma ANP levels in the cardiac function class (NYHA) ${ }^{10}$. 

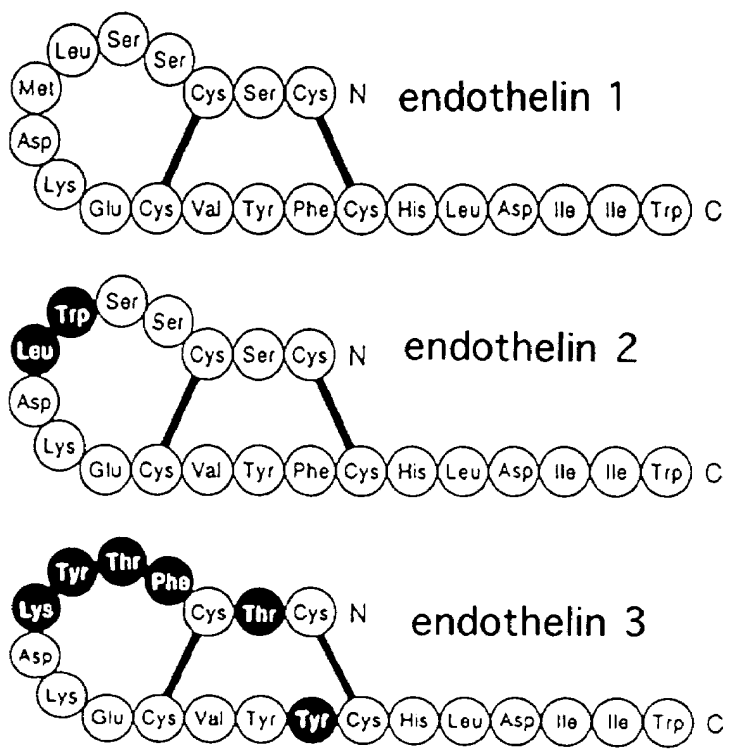

Fig. 7 Endothelin family.

III度では $239 \pm 19 \mathrm{pg} / \mathrm{ml}$, IV 度では468.8 $04 \mathrm{pg} / \mathrm{ml}$ と心不全の重症度にしたがって血獎 ANP 濃度の上昇が 認められた。慢性心不全の重症度の評価としては，呼吸 困難, 動悸等の自覚症状が診断上重要とされている。し かし，これらの評価法は不正確になることがあると言わ れている. ANP 濃度の測定は，客観的で繰り返し測定で きることから, 心不全の重症度の判定に有用である。

$$
\text { III. エンドセリン }
$$

エンドセリンは，1988年に血管内皮由来の血管収縮性 ホルモンとして単離されだ”.エンドセリンは, 砾知の血 管収縮物質の中でも最も強力な血管収縮および昇王作用 を示すことから注目されてきた。エンドセりンには，3 種類のイソフォームが存在寸る。3 種類のイソフォーム は共通して21残基のアミノ酸から構成され，分子内に2 カ所の S-S 結合が存在する.エンドセリン 1 と 2 を比較 すると 2 力所，エンドセリン 3 は 6 力所のアミノ酸が異 なる、エンドセリン 1 および 2 の血管収縮・昇圧作用は 同等であるが，3 100 分 1 以下と弱いと報告されてい る、しかし，初期にみられる一過性の血管収縮・昇圧作 用は 3 種類とも同等の活性を有すると報告されている(2) (Fig. 7).

心筋梗塞患者のエンドセリン濃度は $4.6 \pm 0.8 \mathrm{pg} / \mathrm{ml}$ $(\mathrm{n}=5)$, 健常者が $2.3 \pm 0.1 \mathrm{pg} / \mathrm{ml}(\mathrm{n}=3)$ を示し両者間 に有意差が認められた（Fig. 8)，急性心筋梗塞における エンドセリンの分泌の機序についてはいくつかの可能性 が考えられている，第一に冠動脈内の血栓形成には凝固 系や血小板凝集が関与する結果，トロンビンや血小板由 来の transforming growth factor (TGF) - $\beta$ が直接血管 内皮でのエンドセリンの産生，分䟤に関与していると考

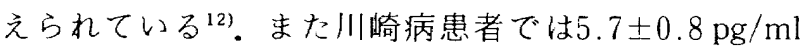

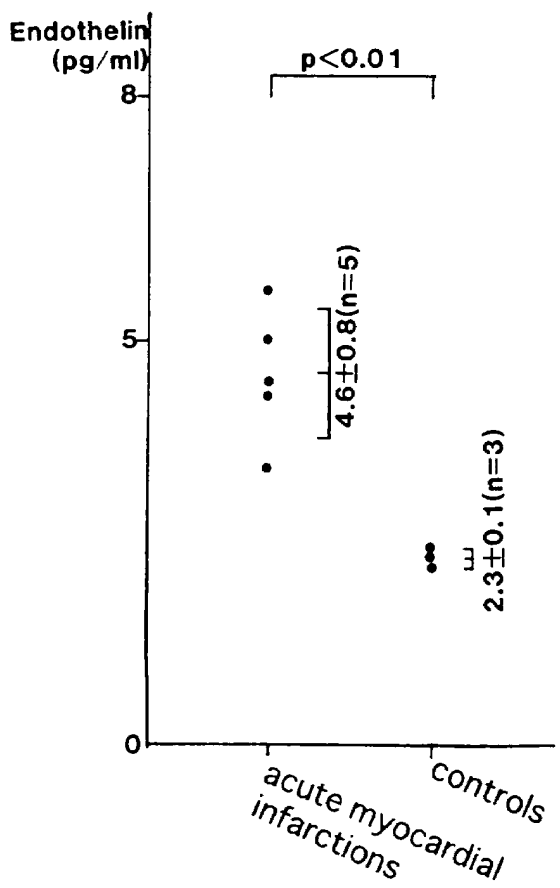

Fig. 8 Assay results of plasma endothelin in acute myocardial infarctions and controls.

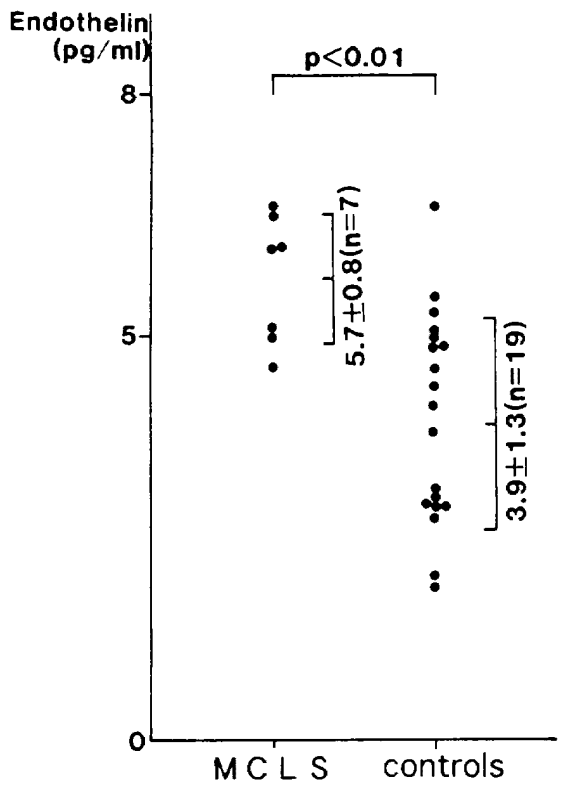

Fig. 9 Assay results of plasma endothelin regarding mucocutaneous-lymph-nodesyndrome (MCLS) and controls.

$(\mathrm{n}=7)$ ，健常児では $3.9 \pm 1.3 \mathrm{pg} / \mathrm{ml}(\mathrm{n}=19)$ を示し両者 間に有意差が認められた（Fig.9）。

以上のように，エンドセリン測定は現在心血管の病態 生理学的に解明する方法として有用であるが，今後さら に臨床的意義については検討しなければならない項目で ある。 


\section{おわりに}

核医学試料測定の進歩は，心疾患の種々の病態を明ら かにし，さらに臨床的には日常検查として広く用いられ ている．しかし，現在のインビトロ検査法は，急性期の 心疾患に対応が不十分であり，画期的な迅速測定法の開 発が望まれている。また低コスト，簡便性および非侵襲 的検査法の利点を生かし, さらに試料測定と画像䛦断法 との関係を明確にし相補性を高めることが今後の課題で ある。

\section{参考文献}

1）永井良三，矢崎義雄，小坂樹徳：ラジオイムノアッ セイによる血中ヒト心筋ミオシン軽鎖 I の測定っよ び急性心筋梗塞症に㧍ける臨床的意義。日本内科学 会誌，70，1098-1104，(1981).

2）矢崎義雄，永井良三，磯部光章：心筋ミオシン軽鎖. 臨床検査ガイド，228-230，(1990)。

3）矢崎義雄, 山沖和秀, 磯部光章, 他：モノクローナ ル抗体を用いた心筋梗塞の核医学的診断。免疫核医 学, 4(2), 41-48, (1989).

4）成田充啓, 栗原 正, 村野謙一, 他：血中心筋ミ才 シン軽鎖 I による急性心筋梗塞定量の有用性. 呼吸 と循環，39(9)，905-910，(1991).
5) Kangawa K, Matsuo H: Purification and complete amino acid sequence of $\alpha$-human atrial natriuretic polpeptide $(\alpha$-hANP). Biochem. Biophys. Res. Comm., 118, 131, (1984).

6) Sudoh $T$, et al.: A new natriuretic peptide in porcine brain. Nature, 332, 78-81, (1988).

7) Sudoh T, et al. : C-type natriuretic peptide family identified in porcine brain. Biochem. Biophys. Res. Commun. 168, 863-870, (1990).

8) 平田結喜緒：ナトリウム利宗ペプチドファミリー. 日本臨床，51(5)，36-44，(1993)。

9）伊藤 裕, 菅 真一, 小川佳宏, 他：ナトリウム利 尿ペプチド系の分子生物学と分子薬理. 日本臨床, 51 (6), 140-153, (1993).

10）蔦本尚慶，金盛俊之，山田浩子，他：慢性心不全の 治療効果判定。循環と計測と制御，8(1)，30-36, (1989)

11) Yanagisawa $M$, et al.: A novel potent rasoconstrictor peptide produced by vascular endothelin cells. Nature. 332, 411-415, (1988).

12）平田結喜緒：エンドセリン・エンドセリン受容体系 の生理的, 病態生理学的役割. 日本臨床, 51(6), 132 -139, (1993). 